\title{
Inter-Company Investments Between Affiliates Of Multinational Enterprises: Applying The Substance-Over-Form Doctrine To Distinguish "Equity" From "Debt"
}

David W. LaRue, (E-mail: dwl2c@ comm.virginia.edu), University Of Virginia Steven C. Thompson, Texas State University

\begin{abstract}
The classification of a financial instrument as "debt" or as "equity" is crucial in applying a wide range of income tax provisions. "Interest" expenses incurred on "debt," for example, are deductible in computing a firm's taxable income, whereas "dividends" paid on the firm's outstanding "equity" are not. "Interest" paid by a U.S. corporation to a foreign creditor is generally not subject to U.S. withholding taxes, whereas "dividends" paid on stock held by a foreign shareholder are typically subject to U.S. withholding taxes that range from 5\% to 30\% of the gross amount of the dividend paid. And the list goes on . . . Not surprisingly, these disparities in tax treatment have inspired a plethora of schemes, many of them successful, designed to disguise equity investments as "debt." The urge to do so is perhaps nowhere more intense than in situations where the "debt" of a U.S. corporation is held by a foreign sister corporation located in a tax haven country. Interest paid or accrued on debt would be deductible in computing the U.S. corporation's U.S. taxable income, and would thereby permanently reduce the debtor's U.S. tax liability. The interest income earned by the foreign creditor would be exempt from both U.S. withholding taxes and income taxes in the foreign tax haven country. This interdisciplinary case was developed from the facts and circumstances before the U.S. Tax Court in litigation that resulted from the government's assertion that $\$ 975$ million in "loans" made by a wholly owned Dutch subsidiary of Laidlaw Transit, Ltd. to several of Laidlaw's U.S. subsidiaries were in substance "equity." As in most debt-versus-equity cases, the stakes were high: Laidlaw's U.S. subsidiaries had deducted over \$133 million of intercompany "payments" made to their Dutch sister corporation as "interest expense" and the IRS was suing to recover \$52 million in back taxes (plus interest and penalties). This case integrates three disciplines - tax accounting, financial accounting, and finance -- in an easy-to-comprehend, yet rich setting appropriate for general management, finance, and accounting audiences. It invites students to thoroughly explore the substance-over-form doctrine as it applies to the debt-versus-equity issue, together with many of the tax, financial, accounting, and economic ramifications that flow from an instrument's classification. It also provides students with an opportunity to identify the ethical issues that attend the formulation and implementation of many tax minimization strategies and to identify factors that separate legal "tax avoidance" from criminal "tax evasion."
\end{abstract}

\section{Introduction}

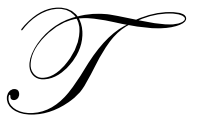

he classification of a financial instrument as "debt" or as "equity" is crucial in applying a wide range of income tax provisions. Interest expenses incurred on "debt," for example, are deductible in computing a firm's taxable income, whereas dividends paid on the firm's outstanding "equity" are not. "Interest" paid by a U.S. corporation to a foreign creditor is generally not subject to U.S. withholding taxes, whereas dividends paid on stock held by a foreign shareholder are typically subject to U.S. withholding taxes that 
range from $5 \%$ to $30 \%$ of the gross amount of the dividend paid. ${ }^{1}$ And the list goes on ....

Not surprisingly, the disparity in the tax treatment of "interest" versus "dividends" has inspired a plethora of schemes, many of them successful, that attempt to disguise true equity as "debt." The urge to do so is perhaps nowhere more intense than in situations where the "debt" of a U.S. corporation is held by a foreign sister corporation located in a tax haven country. Interest paid or accrued on debt would be deductible in computing the U.S. corporation's U.S. taxable income, and would thereby permanently reduce the debtor's U.S. tax liability, but the foreign creditor would not be subject to either U.S. withholding taxes or to income taxes in the foreign tax haven country.

Distinguishing between "debt" and "equity" has become increasingly problematic.

"Generally, we must recognize that the line between equity and debt has become increasingly fuzzy in recent years. Convertible debt has always had an intermediate character, but now there is almost a continuum of securities varying in their relative proportions of debt and equity flavoring. ",

The numerous attempts by Congress and the Treasury Department throughout the last 50 years to establish bright line tests for distinguishing between debt and equity have each ended in failure. The task of classifying instruments has instead, by default, been relegated to the courts, where the various factors deemed relevant in classifying a particular instrument, ${ }^{3}$ and the relative weight given to each factor, have varied widely from one case to the next and from one jurisdiction to another.

\section{Case Objectives}

This interdisciplinary case was developed largely from the facts and circumstances before the U.S. Tax Court in litigation that resulted from the government's assertion that $\$ 975$ million in "loans" made by a wholly owned Dutch subsidiary of Laidlaw Transit, Ltd. ${ }^{4}$ to several of Laidlaw's U.S. subsidiaries were in substance "equity." At stake was the proper classification of over $\$ 133$ million of intercompany payments made by Laidlaw (a U.S. corporation) to a sister corporation located in a tax haven country. If characterized as payments on debt, the amounts would be deductible by the U.S. debtor corporation and permanently reduce Laidlaw's U.S. tax liability by over $\$ 45$ million. These payments would also be exempt from the $\$ 6.65$ million in U.S. withholding taxes that would otherwise be due if the payments were reclassified as dividends. ${ }^{6}$ Conversely, if the instrument on which the underlying payments were made was determined to be "equity," the payments would be treated as nondeductible dividends and they would be subject to substantial U.S. withholding taxes when paid to the foreign creditor.

This case integrates three disciplines: tax law, financial accounting, and corporate finance. It provides tax, accounting, finance, and general management students with an easy-to-comprehend, yet robust setting through which to explore the application of one of the most pervasive doctrines of tax jurisprudence and of financial accounting: the "substance-over-form" doctrine. In this case, students will apply this doctrine to one of the most widespread and persistently troublesome issues in the field of taxation: distinguishing between "debt" and "equity." Although this case addresses that issue in the context of U.S. tax law, the tax laws of most industrialized nations also treat debt (and interest) differently from equity (and dividends) and, like the U.S., they typically resolve the

\footnotetext{
$1 \quad$ The withholding rate on dividends is a function of the tax treaty in effect between the United States and the country in which a foreign shareholder is domiciled. Where there is no tax treaty between the two countries, the statutory withholding rate is a flat $30 \%$.

2 Statement By Alan Greenspan, Chairman, Board Of Governors Of The Federal Reserve System, Before The Committee On Finance, U.S. Senate (January 26, 1989) (89 Tax Notes Today 21-9 (January 27, 1989)).

E.g., whether or not there is a written unconditional promise to pay on demand or on a specified date a sum certain in money, whether the rate of interest is fixed or contingent, whether the obligation is subordinated to debt held by unrelated parties, the corporation's debt-to-equity ratio, whether the instrument is convertible into the stock of the corporation, the between the holdings of stock in the corporation and holdings of the interest in question, etc.

$4 \quad$ Laidlaw Transit, Ltd. was a publicly traded Canadian corporation. Its name has since been changed first to Laidlaw, Inc. and then, in 2003 following its emergence from bankruptcy, to Laidlaw International, Inc.

5 Laidlaw Transportation, Inc. v Commissioner of the Internal Revenue Service, TCM 1998-232. withholding tax

Under the U.S.-Netherlands tax treaty, dividends paid by a U.S. corporation to a Netherlands shareholder were subject to a $5 \%$
} 
classification of ambiguous financial instruments by looking to substance, rather than form.

This case requires minimal understanding of the technical tax or financial accounting rules governing the treatment of debt/interest and equity/dividends. It requires students to focus on the many qualitative and quantitative attributes that distinguish one from the other, and, as noted above, it highlights two of the many substantial tax consequences that result from the classification of a financial instrument as debt or as equity. Many students will be surprised to discover that the form of a transaction and the labels assigned by the parties do not necessarily control the tax or financial accounting treatment where the "substance" of a transaction or financial instrument is at odds with its "form."

The actions of the Laidlaw executives and their tax advisors also provide an opportunity for students to explore the distinction between legal "tax avoidance" and criminal "tax evasion," together with the ethical issues that frequently arise in the course of developing and implementing tax minimization strategies.

This case is designed for use in any graduate or upper-level undergraduate corporate finance, financial accounting, or tax strategy course in which the tax, financial accounting, or economic consequences of corporate debt and/or corporate equity are addressed. Although the barebones issues can be addressed in a single class, the authors prefer to teach this case over two 60-minute sessions,. For the first session, we ask students to read the case and sketch out discussion points for each of the Background Questions. Although most finance, management, and accounting students will have had little, if any, formal exposure to tax law, it has been our experience that most have enough general background to appreciate the issues and to contribute meaningfully to this discussion. We use the second session to build on this background and to focus on the issues that are specific to the Laidlaw case.

The teaching note for this case is both comprehensive and detailed. It provides a considerable amount of background material that non-tax, non-accounting faculty may find especially helpful. University professors can receive an electronic copy of this note from the authors by e-mailing their request to dlarue@ virginia.edu.

\section{Laidlaw Transportation, Inc.}

Born in 1933 in Torhout, Belgium, Michael DeGroote and his parents immigrated to Canada in 1947. They settled in the village of Langdon, Ontario, where 14-year-old Michael started working in the tobacco fields. The long hours of back-breaking labor taught him the value of hard work and kindled an entrepreneurial spirit that would fuel his rise to the very peak of Canada's business elite.

When DeGroote was 18, he bought a second-hand army truck and began hauling manure for local farmers. One truck soon grew to four, then six, then ten, and in 1959 he made his first major strategic move when he acquired all of the stock of Laidlaw Motor Sales, Ltd. and Hepburn Transport Ltd. In 1966, Hepburn Transport Ltd. merged into Laidlaw Motor Sales, Ltd., which later became Laidlaw Transportation, Ltd. ("Laidlaw").

Through DeGroote's aggressive merger and acquisition campaign, Laidlaw and its subsidiaries grew rapidly before and during the years in issue (September 1, 1985-August 31, 1988). ${ }^{8}$ It eventually acquired over 500 other Canadian and U.S. firms in the trucking, solid waste disposal, and passenger bus and school bus service businesses.

These businesses typically used heavy vehicles to transport materials or people and needed governmental licenses or permits to operate. DeGroote, who served as president and chairman of Laidlaw from the time it was formed until August 1, 1990, ${ }^{9}$ believed that the fastest way to expand in these businesses was to buy small privatelyheld businesses which had existing licenses and permits. By the mid- to late-1980's, Laidlaw and its subsidiaries

\footnotetext{
$7 \quad$ On January 1, 1990, Laidlaw Transit, Ltd. changed its name to Laidlaw Inc. In 2001, it filed for bankruptcy protection and emerged two years later as Laidlaw International, Inc.

$8 \quad$ Laidlaw and its subsidiaries used a fiscal year ending on August 31 for both financial reporting and tax purposes.

$9 \quad$ DeGroote owned no less than 50.5 percent of the voting stock of Laidlaw from the time it went public in 1969 though May 1988. Ownership of Laidlaw's other voting stock was widely dispersed. In May 1988, Canadian Pacific, Ltd., the Canadian transportation conglomerate, bought 47.2 percent of the voting stock of Laidlaw from DeGroote for C\$499 million.
} 
had grown to become the largest provider of school bus transportation services in North America, the third largest provider of solid waste disposal services in the United States, and the second or third largest provider of hazardous waste disposal services in the United States.

Laidlaw financed its expansion in the United States by lending money and contributing capital to its subsidiaries in the United States. Before 1969, Laidlaw financed its growth primarily with its own earnings and loans from banks and finance companies. Laidlaw first made a public offering of its stock in 1969 and used the capital it raised to repay bank debts and buy more businesses. Eventually, Laidlaw stock was traded on stock exchanges in both Canada and the United States. ${ }^{10}$

The core management team of Laidlaw and its various subsidiaries during the years in issue consisted of DeGroote, Leslie W. Haworth, and Ivan R. Cairns. Haworth became Laidlaw's senior financial officer in 1972 and later became senior vice president for finance. Cairns became Laidlaw's vice president, general counsel, and secretary in 1981. He later became senior vice president. Cairns and Haworth were DeGroote's two closest advisors on acquisitions, financing, and other matters. Throughout the years in issue, they were directors and officers of Laidlaw and of each of the subsidiaries relevant in this case. DeGroote was chairman of all of the Laidlaw companies.

\section{Laidlaw Transportation, Inc. and Its Subsidiaries}

Throughout the years in issue, Laidlaw, owned all of the stock of Laidlaw Transportation, Inc. ("L_US"), a U.S. holding company formed in 1977. ${ }^{11}$ L_US owned all of the stock of Laidlaw Transit, Inc. ("L_Transit"), ${ }^{12}$ which, along with its numerous subsidiaries, was actively engaged in the passenger and school bus transportation businesses. In 1987, L_US purchased all of the stock Monroe Tree and Lawntender, Inc. for \$16 million and renamed it Laidlaw Tree Service, Inc. ("L_Tree"). ${ }^{13}$

In 1981, L_US formed Laidlaw Industries, Inc. (“L_Industries") as a holding company for Laidlaw's U.S. and Canadian solid waste services operations. ${ }^{14}$ In $1982,21 \%$ of the stock of L_Industries was sold to the public. This stock was re-acquired by L_Industries on December 16, 1987. L_Industries owned all of the stock of Laidlaw Waste Systems, Inc. ("L_Waste"). ${ }^{15}$ In 1987, L_Waste purchased all of the stock of GSX Corporation.

The transportation and waste services industries are capital-intensive. L_US's operating subsidiaries constantly needed large amounts of long-term capital to buy trucks and buses and to improve landfill sites. None of these businesses could afford to eliminate or significantly reduce their capital spending for any substantial period of time without seriously impairing their business operations.

\section{The Coopers and Lybrand Tax Plan}

By the mid-1980's Laidlaw was competing intensely with Browning-Ferris Industries, Inc. and Waste Management, Inc. to buy solid waste services businesses. In the summer of 1985, DeGroote, Cairns, and Haworth asked Coopers \& Lybrand ("C\&L") to develop a tax strategy that would help Laidlaw compete more effectively with Browning-Ferris and Waste Management in buying U.S. companies.

\footnotetext{
10 Trading was suspended in 2002, shortly after Laidlaw filed for bankruptcy protection in Canada and the U.S.

11 DeGroote, Haworth, Ronald S. Murray (Murray), and Douglas R. Gowland (Gowland) were the directors of L_US. DeGroote was president, Gowland was senior vice president for solid waste services, Murray was vice president, Haworth was vice president for finance, and Cairns was secretary.

12 DeGroote, Haworth, and Victor A. Webster (Webster) were L_Transit's directors and its officers included DeGroote as chief executive officer, Webster as president, Haworth as vice president for finance, and Cairns as secretary.

13 DeGroote, Haworth, and Gowland were directors of L_Tree and its officers included Gowland as chairman, Haworth as vice president for finance, and Cairns as secretary.

DeGroote, Haworth, Gowland, and Murray (and others) were directors of L_Industries and its officers included Gowland as president, Haworth was vice president for finance, and Cairns was secretary, vice president, and general counsel.

L_Waste's only directors were DeGroote, Gowland, and Haworth and its officers included Gowland as president, Haworth as vice president for finance, and Cairns as secretary.
} 


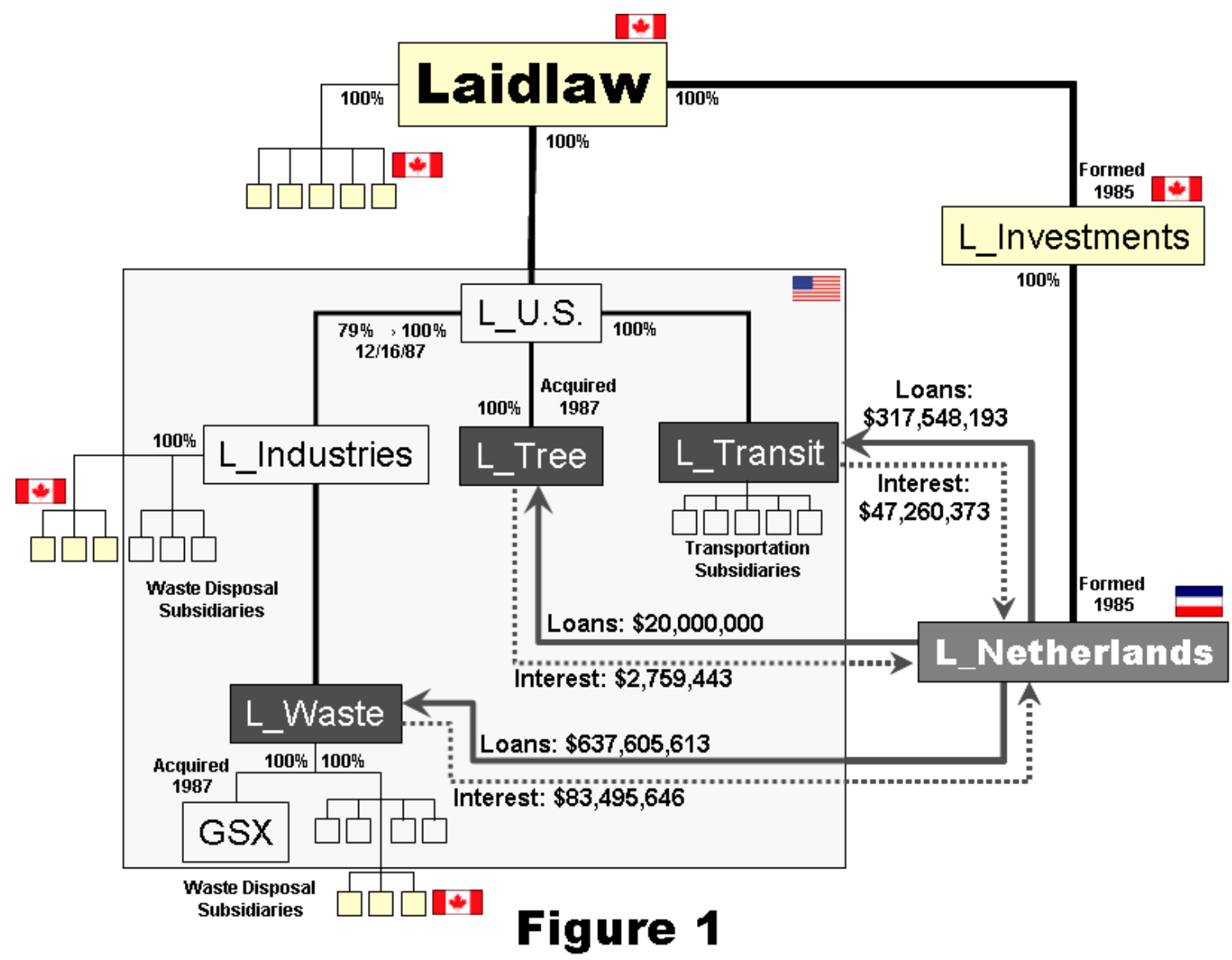

C\&L suggested a plan that was designed to enable Laidlaw to finance a significant portion of its acquisitions with pre-tax dollars, rather than with after-tax dollars. ${ }^{16}$ This could be achieved as follows:

- Laidlaw would form a wholly-owned Canadian subsidiary which, in turn, would form a wholly owned Netherlands subsidiary.

- Laidlaw would then borrow funds from various commercial banks in Canada and then contribute these funds to the capital of the new Canadian subsidiary.

- $\quad$ These funds would then be transferred by the Canadian subsidiary to the Netherlands subsidiary as capital contributions and interest-free loans.

- $\quad$ Finally, the Netherlands subsidiary would advance these funds to Laidlaw's U.S. subsidiaries as interestbearing debt, the proceeds of which would be used by those subsidiaries to effect the acquisitions.

According to C\&L, Laidlaw, in computing its Canadian income tax liability, could deduct the interest it paid on the funds it borrowed to invest in the Canadian subsidiary, and the U.S. subsidiaries could deduct the interest they paid or accrued on the loans made to them by the Netherlands subsidiary in computing their U.S.

\footnotetext{
16 For all of the years in issue, the marginal U.S. income tax rate applicable to the consolidated earnings of Laidlaw's U.S. subsidiaries was $46 \%$.

For federal income tax purposes, "affiliated groups" of U.S. corporations can elect to file consolidated income tax returns with their $80 \%$-orgreater owned U.S. subsidiaries. In stark contrast to the accounting rules governing consolidated financial statements, with require the consolidation of foreign subsidiaries, foreign subsidiaries are neither required nor permitted to join with its U.S. affiliates in filing the U.S. consolidate return. One of the many consequences of this prohibition is that interest paid or accrued by U.S. affiliates to their foreign affiliates is not "eliminated" in the computation of the U.S. group's consolidated taxable income.
} 
income tax liability. Furthermore, the income that the Netherlands subsidiary would derive from the payments of interest made by the U.S. subsidiaries on these loans would be exempt from U.S. withholding taxes ${ }^{17}$ and, under Dutch tax laws, subject to little or no tax in the Netherlands. ${ }^{18}$ When the smoke cleared, the Laidlaw group would have what C\&L called a "double deduction" of interest expense (interest deduction in both Canada and the U.S.), with minimal income tax liabilities in The Netherlands.

\section{Formation Of L_Investments And L_Netherlands}

On September 25, 1985, Laidlaw formed Laidlaw Investments, Ltd. ("L_Investments"), a Canadian corporation with Laidlaw as its sole shareholder. ${ }^{19}$ L_Investments sole sources of funds during the years in issue were the capital contributions made to it by Laidlaw and Laidlaw's other subsidiaries.

On December 30, 1985 L_Investments formed Laidlaw International Investments B.V. ("L_Netherlands") in The Netherlands as a 100-percent owned subsidiary. ${ }^{20}$

\section{Advances at Issue}

Throughout the years in issue, L_Netherlands' primary activity was to receive funds from L_Investments and, on the same or next day, transfer those funds to Laidlaw's U.S. subsidiaries that had requested them: L_Waste, L_Tree, and L_Transit ("U.S. Subsidiaries"). L_Netherlands advanced funds only to the U.S. Subsidiaries (and never to unrelated parties), and its funds came exclusively from Laidlaw (via L_Investments) and from "interest payments" received from the U.S. Subsidiaries.

When a U.S. Subsidiary asked for an advance, L_Netherlands would request L_Investments to provide funds for the transaction. Written agreements between L-Investments and L-Netherlands generally required LInvestments to provide funds requested by L-Netherlands, as long as those amounts were no more than the amounts requested by the U.S. Subsidiaries. L_Investments advanced those funds to L_Netherlands, which, in order to comply with certain Dutch tax rulings that required it to maintain its debt-to-equity ratio within a specified range, recorded them on its books as interest-free demand loans and as capital contributions in proportions designated by C\&L. The February 18, 1986 advance to L_Transit was typical.

- $\quad$ L_Transit requested an $\$ 18$ million advance from L-Netherlands.

- Laidlaw transferred $\$ 18$ million it had received from an earlier issue of its preferred shares ${ }^{21}$ to LInvestments in exchange for additional shares of L-Investments stock. ${ }^{22}$

- $\quad$ L-Investments transferred \$18 million to L-Netherlands in exchange for additional stock and non-interestbearing notes.

- $\quad$ L-Netherlands transferred \$18 million to L_Transit in exchange for an \$18 million interest-bearing note.

\footnotetext{
17 Foreign corporations earning passive investment-type income from U.S. sources are generally subject to income taxes at a flat $30 \%$ tax rate imposed on the gross amount of the income. In order to actually collect the U.S. income taxes owed by foreign taxpayers, the U.S., like most countries, requires U.S. payor corporations to withhold the required taxes from the payments they make to foreign corporations, and to pay these withheld amounts over to the Internal Revenue Service on behalf of the foreign payee.

Tax treaties between the U.S. and each of over 40 countries around the world typically contain provisions that substantially reduce the withholding tax rate on certain types of income. Under the U.S.-Netherlands tax treaty in effect throughout the years in issue, the treaty rate on interest income received by a foreign corporation from a U.S. corporation was $0 \%$, while the tax rate applicable to dividends paid by a U.S. corporation to its foreign parent corporation was only $5 \%$.

18 In October 1987, the Netherlands subsidiary established a branch office in Curacao, Netherlands Antilles, in order to further reduce Netherlands income tax on the interest payments that it received from the U.S. subsidiaries.

19 DeGroote, Haworth, and Cairns were directors of L_Investments and its officers included DeGroote as president, Haworth as vice president for finance, and Cairns as vice president and secretary. Jerry Pekaruk was controller and reported to Haworth.

${ }_{20}$ DeGroote was a director of L_Netherlands during the years in issue. L_Netherlands had other directors, including Netherlands residents.

The funds used to make the advances sometimes came from Laidlaw's own retained earnings, sometimes from loans received by Laidlaw or its subsidiaries from commercial banks, and sometimes, as here, from sales of Laidlaw equity to the public.

$22 \quad$ Laidlaw owned $100 \%$ of the outstanding stock of L_Investments at all times.
} 
By the August 31, 1988, advances to the U.S. Subsidiaries totaled:

$$
\begin{array}{lr}
\text { L_Waste: } & \begin{array}{r}
\$ 231,455,000 \\
\text { L_Industries: }
\end{array} \\
\text { L_Tree totaled: } & 203,157,613 \\
\cline { 2 - 2 } & \$ 854,612,613
\end{array}
$$

L-Netherlands kept books in The Netherlands in which it recorded its lending and borrowing transactions, capital contributions, income, and expenses. L-Netherlands reported the interest payments it received from the U.S. Subsidiaries as interest income subject to The Netherlands' income tax. L-Netherlands paid small amounts of income tax to The Netherlands in 1986, 1987, and 1988. The U.S. Subsidiaries recorded the advances received from L_Netherlands as loans on their books and in their financial statements, and treated all interest payments as interest expense on their financial statements and on the consolidated tax return of the L_US and L_Industries groups. ${ }^{23}$

\section{Interest reinvestment loans}

On the same day that L_Netherlands received "interest payments" from the U.S. Subsidiaries, it would loan all or most of these amounts back to the U.S. Subsidiaries as "interest reinvestment loans." The August 28, 1986 interest payments made by L_Transit and L_Waste was typical.

\begin{tabular}{|l|lr|rc|}
\hline & \multicolumn{2}{|c|}{$\begin{array}{l}\text { U.S. Subsidiaries } \\
\text { to L_Netherlands } \\
8 / 28 / 1986\end{array}$} & $\begin{array}{c}\text { L_Netherlands to } \\
\text { U.S. Subsidiaries } \\
8 / 28 / 1986\end{array}$ \\
\hline L_Waste & $\$$ & 573,958 & $\$$ & - \\
\hline L_Transit & $\$$ & $1,630,716$ & $\$$ & $2,204,674$ \\
\hline & $\$$ & $2,204,674$ & $\$$ & $2,204,674$ \\
\hline
\end{tabular}

1. $\quad$ L_Industries borrowed $\$ 573,958$ from Royal Bank of Canada.

2. $\quad$ L_Industries loaned $\$ 573,958$ to L_Waste and wired that money to L_Waste's account at ABN Bank (New York).

3. $\quad$ L_Waste transferred the $\$ 573,958$ to L_Netherlands' account at ABN Bank (New York).

4. $\quad$ L_Transit transferred $\$ 1,630,716$ to L_Netherlands ABN Bank (New York) account.

5. L-Netherlands transferred \$2,204,674 from its ABN Bank (New York) account to L_Transit's commercial account at Royal Bank of Canada.

During the years in issue, $90 \%$ of the total interest payments made by the U.S. Subsidiaries were loaned back to the U.S. subsidiaries as interest reinvestment loans. L_Netherlands used the interest payments it retained to pay its operating costs, Dutch income taxes, and to make distributions to L_Investments.

23 This fact is of little practical significance in that under U.S. and Canadian accounting standards, all of the entities depicted in Figure 1 were members of the same consolidated group and all intercompany loans, income, expenses, etc. were eliminated in the preparation of Laidlaw's consolidated financial statements. 


\begin{tabular}{|c|c|c|c|c|c|c|}
\hline \multicolumn{7}{|c|}{ Figure 2} \\
\hline & \multicolumn{3}{|c|}{$\begin{array}{c}\text { Interest Payment Claimed to Have Been Made to } \\
\text { Laidlaw-International }\end{array}$} & \multirow{2}{*}{$\begin{array}{c}\text { Total Claimed } \\
\text { Payments (and } \\
\text { Total Deducted } \\
\text { on U.S. Tax } \\
\text { Returns) }\end{array}$} & \multicolumn{2}{|c|}{$\begin{array}{l}\text { Interest Reinvestment Loan } \\
\text { From Laidlaw-International }\end{array}$} \\
\hline & From Transit & $\begin{array}{c}\text { From Laidlaw- } \\
\text { Waste }\end{array}$ & $\begin{array}{l}\text { From Laidlaw- } \\
\text { Tree }\end{array}$ & & $\begin{array}{l}\text { To Laidlaw- } \\
\text { Transit }\end{array}$ & $\begin{array}{l}\text { To Laidlaw- } \\
\text { Waste }\end{array}$ \\
\hline $5 / 29 / 1986$ & 809,057 & 179,740 & $\$$ & 988,797 & 988,797 & \\
\hline $8 / 28 / 1986$ & $1,630,716$ & 573,958 & - & $2,204,674$ & $2,204,674$ & \\
\hline $11 / 25 / 1986$ & $3,097,820$ & $2,772,450$ & - & $5,870,270$ & $5,870,270$ & \\
\hline $2 / 25 / 1987$ & $4,003,389$ & $7,532,238$ & - & $11,535,627$ & $11,535,627$ & \\
\hline $5 / 28 / 1987$ & $4,479,972$ & $7,988,179$ & - & $12,468,151$ & $12,468,151$ & \\
\hline $8 / 31 / 1987$ & $5,071,716$ & $10,297,291$ & 546,667 & $15,915,674$ & $15,280,674$ & \\
\hline $11 / 30 / 1987$ & $5,705,723$ & $10,597,883$ & 549,028 & $16,852,634$ & $16,700,000$ & \\
\hline 2/29/1988 & $6,346,874$ & $11,991,976$ & 539,583 & $18,878,433$ & & $12,448,000$ \\
\hline $5 / 31 / 1988$ & $7,534,621$ & $15,015,471$ & 542,499 & $23,092,591$ & $21,045,000$ & \\
\hline $8 / 31 / 1988$ & $8,580,485$ & $16,546,460$ & 581,666 & $25,708,611$ & & $22,000,000$ \\
\hline \multirow{2}{*}{ Totals: } & $47,260,373$ & $\$ \quad 83,495,646$ & $2,759,443$ & $\$ 133,515,462$ & $86,093,193$ & $\$ \quad 34,448,000$ \\
\hline & \multicolumn{3}{|c|}{$\$ 133,515,462$} & & \multicolumn{2}{|c|}{$\$ 120,541,193$} \\
\hline
\end{tabular}

By August 31, 1988, the U.S. Subsidiaries owed L_Netherlands a total of $\$ 975,153,806$ in advances and interest reinvestment loans. ${ }^{24}$

\begin{tabular}{|c|c|c|c|c|c|c|c|c|}
\hline & & $\begin{array}{r}\text { Advance } \\
\text { Decen }\end{array}$ & be & $\begin{array}{l}\text { Figure } 3 \\
\text { Leadlav } \\
985 \text { through }\end{array}$ & 10 & $\begin{array}{l}\text { ternatio } \\
t, 1988^{10}\end{array}$ & ial & \\
\hline & & & & orrower & & & & Total \\
\hline & & Transit & & Waste & & Tree & & \\
\hline FY 8608 & $\$$ & $118,893,471$ & $\$$ & $29,000,000$ & $\$$ & - & $\$$ & $147,893,471$ \\
\hline FY 8708 & $\$$ & $88,954,722$ & $\$$ & $376,212,613$ & $\$$ & $20,000,000$ & $\$$ & $485,167,335$ \\
\hline FY 8808 & $\$$ & $109,700,000$ & $\$$ & $232,393,000$ & $\$$ & - & $\$$ & $342,093,000$ \\
\hline Total & $\$$ & $317,548,193$ & $\$$ & $637,605,613$ & $\$$ & $20,000,000$ & $\$$ & $975,153,806$ \\
\hline
\end{tabular}

Uses of the L_Netherlands Advances

- $\quad$ L_Transit

- $\quad$ L_Transit used the funds advanced to it by L_Netherlands to acquire the stock and assets of 44 U.S. companies in the transportation industry and to expand their respective operations.

- $\quad$ L_Waste

○ $\quad$ L_Waste used $\$ 349.8$ million of the advances from L_Netherlands to purchase all of the stock GSX on October 14, 1986.

- $\quad$ Another $\$ 60.9$ million of the advances were initially made to L_Industries on December 16,1987 and used buy back the $21 \%$ of its stock held by the public in December of 1987 . This obligation was assumed by L-Waste later that same day.

- The balance of the advances made by L_Netherlands to L-Waste were used primarily to acquire 30 companies in the solid waste services industry and to expand their respective operations.

24 L_Netherlands continued to advance money to L_US, L_Transit, L_Waste, L_Tree, and other L_US subsidiaries after August 31 , 1988. By December 31, 1994, L_Netherlands had advanced a total of $\$ 1,393,383,974$ to Laidlaw's U.S. subsidiaries. 
- $\quad$ L_Tree

- Laidlaw Acquisition Corporation (“L_Acquisition”) borrowed $\$ 20$ million from L_Netherlands on May 27, 1987 and used these amounts to purchase all of the stock of L_Tree ( $\$ 1 \overline{6}$ million) and to refinance third-party loans relating to $L_{-}$Tree's purchase of rolling stock ( $\$ 4$ million). Immediately after the acquisition, L_Tree assumed the L_Acquisition's $\$ 20$ million obligation to L_Netherlands and L_Acquisition liquidated into L_U.S.

\section{General Terms and Conditions of Loan Agreements}

Throughout the years in issue, DeGroote, Haworth, and Cairns significantly influenced and directed L_Netherland's lending decisions and operations. During this period, L_Netherlands' managing directors met 12 times. DeGroote was present at four of the meetings and voted by proxy at eight. Haworth was present at three of those meetings and Cairns was present at two. Additionally, L_Investments' proxies at shareholder meetings for L_Netherlands included specific instructions about future transactions. Cairns and Haworth signed, on behalf of the U.S. Subsidiaries, all of the loan agreements, promissory notes, and assignments of transactions between L_Netherlands and the U.S. Subsidiaries.

Laidlaw's counsel, Cairns, wrote the first draft of all of the L_Netherlands loan agreements. Initially, the agreements between L_Netherlands and the U.S. subsidiaries receiving the advances provided that (a) the borrower's obligation to pay interest and principal was unconditional, (b) the loan must be repaid on or before a fixed date or on demand, (c) the interest rate was fixed and the borrower's/guarantor's obligation to pay interest was unconditional and neither the timing or amount was contingent on whether the borrower (or the guarantor) had any income or whether it made any dividend distributions, (d) L_US would guarantee all loans made to L_Tree and L_Transit, and L_Industries would guarantee all loans made to L_Waste, ${ }^{25}$ (d) L_Netherlands' rights were senior to the rights of the stockholders of the borrower and the guarantor, and (e) the loan could not be converted into the stock of the borrower. Advances made by L_Netherlands to the U.S. Subsidiaries were not subordinated to loans made by commercial banks. L_Transit was required to maintain and long-term debt to equity ratio of no more than 2:1 and a current assets to current liabilities ratio of no less that 1:1. L_Waste agreed to limit its debt to equity ratio to no more than $2.5: 1$.

These initial loan agreements did not require the directors of the L_Waste or L_Transit to make periodic principal payments, but they did permit the borrower to convert the loans to 5 -year term loans on or before September 1, 1988, the maturity date on which the entire principal amount would otherwise be due. In all events, L_Netherlands could demand repayment of the entire outstanding at any time if it needed the funds. These agreements did not require the borrower or its guarantor to create a reserve or sinking fund to assure the timely repayment of the advances.

Throughout the years in issue, Laidlaw, L_US, L_Industries, L_Waste, and L_Tree had substantial credit lines and outstanding loans from unrelated commercial banks. The terms of these loans, detailed more fully below, established leverage ratio criteria. Generally, the borrower's consolidated total debt-to-equity ratio could not exceed 2:1 and its working capital ratio (current assets over current liabilities) could not fall below 1:1. L_US and/or L_Industries guaranteed repayment of all advances from commercial banks to L_Transit, L_Tree, and L_Waste.

The \$349.8 million debt-financed acquisition of GSX on October 14, 1986 caused Laidlaw, L_US, and L_Industries to become highly leveraged and in technical default on their loans from commercial lenders. Consequently, on October 16, 1986, in order to prevent default, Haworth (in a letter written on L_US letterhead) informed the directors of L_Netherlands that its loan agreements with the U.S. Subsidiaries would have to be amended to subordinate the repayment of those advances (and interest) to the loans received by Laidlaw and its subsidiaries from commercial banks. Also in that letter, Haworth instructed the L_Netherlands board to approve the

25 Although Laidlaw guaranteed repayment of loans made by unrelated commercial lenders to the U.S. Subsidiaries, it did not guarantee repayment of loans that L-Netherlands made to the U.S. Subsidiaries. 
following amendments to existing and future loan agreements between L_Netherlands and the U.S. Subsidiaries, and to make those amendments retroactive back to September 1, 1986:

- $\quad$ “(a) All sums to be due on demand at interest rates equal to ABN Bank (New York) prime plus 2 percent, payable on the last business days of each fiscal quarter.

- $\quad$ "(b) Remove all financial ratio covenants.

- $\quad$ “(c) Remove the 'ceilings' so that no limits will exist. All loans will be provided as requested but subjected to availabilities of [L_Netherlands]'s funds.

- $\quad$ “(d) In the case of [L_U.S.]'s subsidiaries, there will be two loan accounts established, one called principal account and the other called reinvested interest account.

- $\quad$ "(e) To facilitate the quarterly and other changes in loan amounts, all increases/decreases would be entered on a grid promissory note. This system allows the lender to adjust the promissory note automatically without issuing a new note."

These amendments were unanimously approved by the L_Netherlands board on October 20, 1986 and given retroactive effect back to September 1, 1986.

On July 7, 1987, the agreements were further modified, retroactively back to September 1, 1986, to eliminate the demand feature, to add some enforcement provisions (including an acceleration clause in the event of default), and to postpone the due date for the payment of principal by one year to September 1, 1989, "unless the parties extended the due date by written agreement."

On September 12, 1988, the members of the L_Netherlands board of directors discussed repayment by advances made to the U.S. Subsidiaries. At that time, the advances were due to be repaid on September 1, 1989. The board decided to extend the repayment date. The minutes for that meeting stated that L_Netherlands' management did not intend to request repayment. In fact, from the date of the initial advance through October, 1989 , none of the principal amounts of the advances or the interest reinvestment loans had been repaid. ${ }^{26}$

\section{Comparison of Loans from Commercial Banks with Loans from L_Netherlands}

Similarities. The commercial bank loans and L_Netherlands advances for the years in issue were in writing. All were for general corporate purposes or for the acquisition of other businesses. All had some representations and warranties to the bank or L_Netherlands about the financial conditions of the borrower. All required corporate existence and authority, punctual payments, some type of periodic reporting, and notice of default. All imposed limitations on further encumbering any security. All treated nonpayment, incorrect or false representations, noncompliance with material terms and conditions, insolvency or bankruptcy, and other similar events as a default. Most had cross-default clauses and acceleration clauses. Most were guaranteed by a parent. All allowed prepayment without penalty.

Differences. Commercial bank loans always had borrowing limits. The amounts that the U.S. Subsidiaries could borrow from L_Netherlands was generally not limited. Commercial banks lent substantially less to the U.S. Subsidiaries than L_Netherlands advanced to them. Over half of the L_Netherlands advances were more than \$100 million, but most of the bank loans were substantially less than $\$ 100$ million. Bank loans were generally for a 5-year period and no bank loan had a demand feature. L_Netherlands advances were generally not payable over a fixed term and generally had demand features. L_Netherlands generally did not require the U.S. Subsidiaries to make quarterly or semiannual payments of principal, but did allow balloon payments. Commercial banks required quarterly or semiannual payments of principal and did not allow balloon payments. Commercial banks required minimum debt-to-equity and current-assets-to-current-liabilities ratios. L_Netherlands, after September 1, 1986, generally did not.

\footnotetext{
26 As of the date that this case went to trial in 1997, the U.S. Subsidiaries had not reduced the total unpaid balances that they owed to L_Netherlands below the $\$ 975,153,806$ which was outstanding as of August $31,1988$.
} 
The guaranties differed in that the commercial banks required that the guarantors to post collateral and that they meet financial requirements. L_Netherlands did not.

Only bank loans had negative covenants that limited the use of the borrowed funds, or placed limitations on a change of the borrower's business or on asset dispositions. L_Netherlands advances did not. Commercial bank loans generally had more covenants and warranties relating to the borrower's legal status and activities (e.g., compliance with ERISA and securities laws) than L_Netherlands advances. Banks treated material adverse changes in the borrower's operations or financial condition, certain judgments, and liquidation, dissolution, or winding up of the borrower's business as events of default. L_Netherlands did not.

\section{Audit of LTL by Canadian Tax Authorities}

Canadian income tax authorities audited Laidlaw for 1987 and 1988. In connection with that audit, Laidlaw represented that: "Laidlaw Inc. acts as a conduit in providing funds for its operating subsidiaries. The funds are used by the subsidiaries as working capital and for capital acquisitions. Without these funds, the subsidiaries would be seriously undercapitalized. The loans are in the nature of capital contributions to the subsidiaries."

\section{Discussion Questions}

\section{Background}

1. In what ways do the income tax and financial accounting treatment of "debt" (and "interest") and "equity" (and "dividends") differ? What is the practical significance of each of these differences?

2. "Substance" over "Form": Assume the following facts:

- $\quad \mathrm{F}$ is the sole shareholder of a regular corporation that is taxable at the combined federal and state tax rate of $40 \%$. F's personal tax rate for federal and state income taxes is $45 \%$. The corporation pays a lump-sum $\$ 100,000$ salary to $S$, one of its employees, on June 15 th of the current year. This is S's only income for the year and it is subject to an effective combined federal and state income tax rate of $30 \%$.

- $\quad$ To the naked eye, the corporation should be entitled to a $\$ 100,000$ salary expense deduction that will save it $\$ 40,000$ in federal and state income taxes. S should report $\$ 100,000$ of ordinary salary income on his tax return for the year and pay a total of $\$ 30,000$ of income taxes on that amount.

- But what if you learned that $F$ is the father of $S$ ? What if $S$ is 18 years old and graduated from high school on June $15^{\text {th }}$ and will attend a private college the following fall? And what if the only service that $\mathrm{S}$ has ever performed for the corporation was to spend a couple of hours each Saturday morning in May sweeping up the factory floor?

- Can the Internal Revenue Service ignore the form of a transaction and the descriptive labels (e.g., "salary") used by the parties? If so, what tax consequences might you expect to result to the corporation, to $\mathrm{F}$, and to $\mathrm{S}$ in the light of these additional facts?

3. "Debt" versus "Equity: Generally, what are some of the attributes of "debt" that distinguish it from "equity"? What additional facts and circumstances might be probative in distinguishing "debt" from "equity"?

4. Is it legal and ethical for individuals and corporations to arrange their affairs and structure their transactions in ways that eliminate, minimize or postpone their tax liability?

\section{Laidlaw's Intercompany "Debt"}

1. The principal issue in this case was whether the amounts loaned by L_Netherlands to the U.S. Subsidiaries were, in substance, equity, rather than debt. If these amounts were held to be capital contributions, then all or a part of the $\$ 133,515,459$ denominated as "interest" and deducted by the U.S. Subsidiaries in computing their U.S. income tax liabilities would be re-classified as nondeductible dividend distributions and the U.S. Subsidiaries would be liable for over $\$ 45$ million in additional income taxes, plus interest and 
penalties on those taxes. Furthermore, under the U.S.-Netherlands tax treaty, interest paid by a U.S. debtor to a foreign corporation was not subject to U.S. withholding taxes, whereas dividends paid to foreign shareholders were subject to a 5\% withholding tax. Discuss the respective merits of Laidlaw's contention that these loans were in form and in substance bona fide "debt" and the government's contention that they were in substance "equity."

2. Even if the Taxpayer prevailed on the debt-versus-equity issue, it would also have to deal with Section 267(a)(2) of the Internal Revenue Code under which accrual method taxpayers are generally not entitled to a deduction for expenses owed to related parties until those expenses were actually "paid." The issue here would be whether the "payments" made by the U.S. Subsidiaries to L_Netherlands and immediately loaned back to them constituted "payment" as that term was used in Section 267(a)(2). Your thoughts?

3. If you concluded either that (1) the "loans" were in substance "equity" or that (2) the interest paid and then re-loaned back to the U.S. Subsidiaries was not in substance "paid" (as required by Section 267(a)(2)), then discuss the ethics and the legality (an attempt at legitimate "tax avoidance" or approaching or even crossing the line into criminal "tax evasion") of the strategy crafted by Coopers and Lybrand and implemented by the Laidlaw executives.

Please see table on next page. 


\begin{tabular}{|c|c|c|c|c|c|c|c|c|}
\hline \multicolumn{9}{|c|}{$L_{\text {_ Industries }}$} \\
\hline Fiscal Year Ending: & & 8508 & & 8608 & & 8708 & & 8808 \\
\hline Tangible Net Worth & $\$$ & $57,022,000$ & $\$$ & $84,341,000$ & $\$$ & $42,659,000$ & $\$$ & $(22,630,000)$ \\
\hline Quick Ratio** & & 0.93 & & 1.12 & & 1.3 & & 1.17 \\
\hline Current Ratio* & & 1.33 & & 1.62 & & 1.62 & & 1.32 \\
\hline Debt/Equity Ratio $^{\dagger}$ & & 0.59 & & 0.67 & & 3.54 & & 8.43 \\
\hline Liabilities/Equity Ratio & & 0.87 & & 0.89 & & 4.05 & & 9.42 \\
\hline Liab./Tang. Net Worth Ratio & & 1.38 & & 1.31 & & 13.35 & & $\mathrm{~N} / \mathrm{A}$ \\
\hline EBIT/Interest Expense ${ }^{*}$ & & 8.93 & & 7.89 & & 1.9 & & 1.65 \\
\hline Free Cash Flow ${ }^{+}$ & & $\mathrm{N} / \mathrm{A}$ & $\$$ & $(3,177,391)$ & $\$$ & $(294,312,141)$ & $\$$ & $(67,858,322)$ \\
\hline (EBITDA-CAPEX)/Interest Expense & & 0.94 & & -0.77 & & -7.81 & & -1.16 \\
\hline \multicolumn{9}{|c|}{ L-US } \\
\hline Fiscal Year Ending: & & 8508 & & 8608 & & 8708 & & 8808 \\
\hline Tangible Net Worth & $\$$ & $18,865,000$ & $\$$ & $28,400,000$ & $\$$ & $(33,204,000)$ & $\$$ & $(58,027,000)$ \\
\hline Quick Ratio** & & 87 & & 0.76 & & 0.83 & & 1.02 \\
\hline Current Ratio* & & 1.16 & & 1.36 & & 1.12 & & 1.58 \\
\hline Debt/Equity Ratio $^{\dagger}$ & & 1.61 & & 2.26 & & 5.78 & & 5.63 \\
\hline Liabilities/Equity Ratio & & 2.76 & & 3.26 & & 7.29 & & 6.44 \\
\hline Liab./Tang. Net Worth Ratio & & 9.93 & & 12.02 & & $\mathrm{~N} / \mathrm{A}$ & & $\mathrm{N} / \mathrm{A}$ \\
\hline EBIT/Interest Expense & & 7.14 & & 3.38 & & 1.82 & & 1.5 \\
\hline Free Cash Flow ${ }^{+}$ & & $\mathrm{N} / \mathrm{A}$ & $\$$ & $(63,490,919)$ & $\$$ & $(351,973,233)$ & $\$$ & $(109,555,409)$ \\
\hline (EBITDA-CAPEX)/Interest Expense & & -4.04 & & -3.92 & & -6.15 & & -1.19 \\
\hline \multicolumn{9}{|c|}{ L-Transit } \\
\hline Fiscal Year Ending: & & 8508 & & 8608 & & 8708 & & 8808 \\
\hline Tangible Net Worth & $\$$ & $(7,020,000)$ & $\$$ & $(18,734,000)$ & $\$$ & $(21,529,000)$ & $\$$ & $(56,284,000)$ \\
\hline Quick Ratio** & & 0.13 & & 0.4 & & 0.77 & & 0.81 \\
\hline Current Ratio* & & 0.22 & & 0.57 & & 1.13 & & 1.11 \\
\hline Debt/Equity Ratio $^{\dagger}$ & & 9.94 & & 10.52 & & 9.43 & & 15.44 \\
\hline Liabilities/Equity Ratio & & 11.17 & & 11.71 & & 10.66 & & 16.87 \\
\hline Liab./Tang. Net Worth Ratio & & $\mathrm{N} / \mathrm{A}$ & & $\mathrm{N} / \mathrm{A}$ & & $\mathrm{N} / \mathrm{A}$ & & $\mathrm{N} / \mathrm{A}$ \\
\hline EBIT/Interest Expense & & 2.66 & & 1.98 & & 1.59 & & 1.06 \\
\hline \multicolumn{9}{|c|}{ L-Tree } \\
\hline Fiscal Year Ending: & & 8508 & & 8608 & & 8708 & & 8808 \\
\hline Tangible Net Worth & $\$$ & - & $\$$ & $4,354,000$ & $\$$ & $(11,666,000)$ & $\$$ & $(5,711,000)$ \\
\hline Quick Ratio** & & - & & 1.4 & & 1.16 & & 1.47 \\
\hline Current Ratio* & & - & & 1.53 & & 1.23 & & 1.61 \\
\hline Debt/Equity Ratio $^{\dagger}$ & & - & & 0.87 & & 95.86 & & 3.09 \\
\hline Liabilities/Equity Ratio & & - & & 1.54 & & 109.84 & & 3.43 \\
\hline Liab./Tang. Net Worth Ratio & & - & & 1.55 & & $\mathrm{~N} / \mathrm{A}$ & & $\mathrm{N} / \mathrm{A}$ \\
\hline EBIT/Interest Expense & & - & & 8.3 & & 1.85 & & 1.00 \\
\hline \multicolumn{9}{|c|}{$\begin{array}{l}\text { \# Financial data for L_Waste was unavailable, but financial data for L-Industries, its immediate parent, and L_US, L_Industries } \\
\text { immediate parent, was available and is included in this chart. }\end{array}$} \\
\hline \multicolumn{9}{|c|}{ * "Current ratio" is current assets (cash and equivalents, receivables, and inventories) divided by current liabilities. } \\
\hline \multicolumn{9}{|c|}{ ** "Quick ratio" is cash and equivalents and receivables, or current assets less inventories, divided by current liabilities. } \\
\hline \multicolumn{9}{|c|}{${ }^{\dagger}$ Laidlaw's competitors in the waste services industry during 1987 and 1988 generally had debt to equity ratios below 2 to 1.} \\
\hline \multicolumn{9}{|c|}{${ }^{\ddagger}$ EBIT is earnings before interestexpense and taxes } \\
\hline
\end{tabular}


$\underline{\text { Notes }}$ 